\title{
Fundamentos del derecho penal en Indias: el Cursus de Murillo Velarde*
} Fundamentals of Criminal Law in the Indies:
the Murillo Velarde Cursus

\section{Belinda Rodríguez Arrocha**}

\section{RESUMEN}

El Cursus juris canonici, hispani et indici (Madrid, 1743) del jurista Pedro Murillo Velarde y Bravo (1696-1753) es una obra primordial para el estudio de las divergencias y similitudes entre la práctica judicial indiana y la castellana. El autor, perteneciente a la Compañia de Jesús, demuestra exhaustivos conocimientos sobre el derecho real, el canónico y el romano. Asimismo, proyecta su experiencia docente en las frecuentes disertaciones etimológicas contenidas en su libro. El propósito principal de este artículo es hacer una valoración crítica del Cursus como contribución fundamental a la literatura penal indiana. En este sentido, prestamos especial atención a las fuentes normativas y doctrinales presentes en las definiciones de los delitos y las penas, profundizando en el fenómeno juridico y cultural del ius commune. Además, analizamos el tratamiento juridico que se le otorgaba a los reos pertenecientes al clero regular y secular.

PALABRAS CLAVE: derecho indiano, derecho penal, Iglesia, ius commune, Murillo Velarde (Pedro), siglo XVIII.

\begin{abstract}
The Cursus Juris Canonici, Hispani Et indici ( $M a-$ drid, 1743) of the Jurist Pedro Murillo Velarde y Bravo (1696-1753) Is a fundamental work for the study of the divergences and similarities between the Indian and Castile Judicial practices. The author, belonging to the Society of Jesus Christ, demonstrates exhaustive knowledge about Royal, Canonical and Roman Law. He also projects his teaching experience in the frequent Etymological dissertations contained in his book. The main purpose of this article is the critical assessment of the Cursus as a fundamental contribution to the Indian criminal literature. In this sense, we pay special attention to the normative and doctrinal sources presented in the definitions of crimes and penalties and we will deepen in the Juridical and Cultural phenomenon of the lus Commune. We also make analysis of the legal treatment granted to prisoners belonging to the Regular and Secular Clergy.
\end{abstract}

KEY WORDS: Indian law, Criminal law, Church, lus commune, Murillo Velarde (Pedro), Eighteenth century.

\footnotetext{
* Artículo de investigación. Recibido el 13 de junio de 2017 y aceptado para su publicación el 27 de julio de 2018.

** Investigadora en el Instituto de Estudios Canarios (CECEL-CSIC), España. (belindarodrguez@gmail.com) orcid. org/0000-0002-6977-3111
} 


\section{SUMARIO}

1. Introducción: el derecho criminal en el antiguo régimen

2. Perfil biográfico y profesional de Pedro Murillo Velarde

3. Aspectos procesales y tipología delictiva en el Cursus de Murillo

4. Las fuentes del derecho en el Cursus

5. Conclusiones

\section{Introducción: el derecho criminal en el antiguo régimen}

Corría el año de 1969 cuando Francisco Tomás y Valiente publicaba su libro El derecho penal de la monarquía absoluta (siglos XVI-XVII-XVIII), un hito en el ámbito de la historia del derecho del antiguo régimen hispano. ${ }^{1}$ Bernal Sánchez-Arcilla ha matizado con mucho acierto la visión que aporta Tomás y Valiente al derecho criminal de la Edad Moderna. Esto, en lo que concierne a las transformaciones institucionales acaecidas entre los comienzos del siglo XVI y el siglo XVIII, así como a la valoración de las "arbitrarias" actuaciones judiciales, entre otros aspectos. ${ }^{2}$

Empero, no cabe duda de que El derecho penal de la monarquía absoluta aún constituye una ineludible referencia para el conocimiento de los rasgos básicos del derecho real y de la doctrina jurídica criminal y teológica, en el contexto social y político de la monarquía católica. ${ }^{3}$ El autor contribuyó de manera inestimable a la contextualización del derecho positivo y de la doctrina castellana en el marco de la ciencia jurídica del ius commune europeo. ${ }^{4}$ En la época de su publicación, las pesquisas relativas a este trascendente fenómeno cultural en el ámbito penal ya habían dado sus frutos en otros países de la Europa occidental. Mencionemos, por ejemplo, la destacada producción científica de Friedrich Schaffstein, entre otros investigadores.

Otra monografía señera, publicada en la segunda mitad del siglo xx, es El proceso penal en Castilla (siglos XIII-XVIII) de la doctora Paz Alonso. Este

\footnotetext{
1 Tomás y Valiente, Francisco, El Derecho Penal de la Monarquía Absoluta (siglos XVI-XVII-XVIII), Madrid, Tecnos, 1969.

2 Sánchez-Arcilla Bernal, José, "¿Arbitrariedad o arbitrio? El otro Derecho Penal de la otra Monarquía [no] Absoluta", en José Sánchez-Arcilla Bernal, El Arbitrio judicial en el Antiguo Régimen (España e Indias, siglos XVI-XVIII), Madrid, Dykinson, 2013, pp. 9-45.

${ }^{3}$ Una reflexión muy reciente acerca del legado de Francisco Tomás y Valiente en la historiografia criminal es FiESTAS LOZA, ALIIA, "Francisco Tomás y Valiente y la historia del derecho penal", en María Paz Alonso Romero (ed.), Francisco Tomás y Valiente. Memoria y legado de un maestro, Salamanca, Ediciones Universidad de Salamanca, 2016, pp. 109-133.

${ }^{4}$ Masferrer Domingo, Aniceto, "El 'ius commune' en la historiografía penal española. Una apuesta metodológica de apertura hacia lo supranacional y europeo", en Orazio Condorelli (ed.), "Panta rei": Studi dedicati a Manlio Bellomo, tomo 3, Roma, Il Cigno Edizioni, 2004, pp. 563-587.
} 
trabajo es imprescindible para conocer los orígenes románico-canónicos del proceso criminal secular. ${ }^{5}$

En lo concerniente a Nueva España -espacio al que dedicaremos especial atención en el presente artículo-, contamos en la actualidad con importantes contribuciones, relativas a la justicia criminal, desde la perspectiva de la historia del derecho. En este sentido, la doctora Adriana López ha analizado con atención el rol que desempeñó el derecho indiano ${ }^{6}$ en la resolución de conflictos entre la cosmovisión indígena y la cristiana, en el área de San Luis Potosí, durante la segunda mitad del siglo xVIII. Al mismo tiempo, esta autora ha identificado los orígenes prehispánicos de algunas instituciones jurídicas contempladas por la legislación indiana. ${ }^{7}$

También sobresalen las investigaciones de García León, cuya tesis doctoral versó sobre la aplicación del derecho castellano procesal y criminal en el área de la Mixteca Alta, durante la época colonial. Ha abordado además la redacción de formularios novohispanos tendentes a la instrucción en los fundamentos del proceso criminal. Éstos constituyen valiosas fuentes para la dilucidación de las características de la práctica judicial en el periodo virreinal. ${ }^{8}$ Asimismo, el doctor Sánchez-Arcilla ${ }^{9}$ ha estudiado exhaustivamente la actividad judicial penal de la Ciudad de México, de la segunda mitad del siglo xvIII.

Por otra parte, la interpretación del doctor García Marín acerca de la administración judicial en Nueva España ha incidido en los defectos del ordenamiento jurídico de la época. ${ }^{10}$ Las más recientes aportaciones efectuadas por jóvenes historiadores del derecho implican un avance significativo en el conocimiento del proceso criminal de los siglos XVI y XVII - menos estudiados que el XVIII novohispano-. Estas aportaciones, además, contribuyen a una profundización en el ejercicio del arbitrio judicial. ${ }^{11}$

\footnotetext{
${ }^{5}$ Alonso Romero, Maria PAZ, El proceso penal en Castilla (siglos XIII-XVIII), Salamanca, Universidad de Salamanca - Diputación Provincial de Salamanca, 1982.

${ }^{6}$ El derecho indiano quedó paulatinamente configurado como un derecho particular emanado del propio derecho castellano y con unos contornos bien definidos. MarTiRÉ, EdUARDo, "Algo más sobre derecho indiano (entre el ius commune medieval y la modernidad)", Anuario de historia del derecho español, España, Ministerio de Justicia, 2003, p. 261.

7 López Ledesma, Adriana, "El Derecho Prehispánico en el Derecho Indiano: Causa criminal en la Nueva España por acciones indecentes y sublevación indígena", Cuadernos de Historia del Derecho, núm. 13, 2006, pp. 31-109.

${ }^{8}$ Garcia León, Susana, "Un formulario de causas criminales de la Nueva España", Anuario Mexicano de Historia del Derecho, núm. 9, pp. 83-148.

9 Sánchez-Arcilla Bernal, José, Jueces, criminalidad y control social en la ciudad de México a finales del siglo XVIII, Madrid, Dykinson, 2016.

${ }^{10}$ Garcia Marin, José MariA, "La Justicia del Rey en la Nueva España. Algunos aspectos. Siglos XVI-XVIII", Anuario de historia del derecho español, núm. 75, pp. 85-180.

${ }^{11}$ Hernández Santiago, Óscar, "La justicia criminal novohispana. Entre la culpa del delincuente y la misericordia del juez", en Gustavo César Machado Cabral, Francesco Di Chiara, Óscar Hernández Santiago, Belinda Rodríguez Arrocha, Karl Härter, El derecho penal en la edad moderna. Nuevas aproximaciones a la doctrina y a la práctica judicial, Madrid, Universidad Carlos III de Madrid - Dykinson, 2016, pp. 111-148.
} 
Pertinentes reflexiones acerca del ius commune han señalado que no podemos considerar la existencia de dos órdenes jurídicos opuestos: el derecho común y los derechos patrios. Más bien, cabría sostener su coexistencia y la valoración de las necesidades del caso particular en el acto de impartir justicia. ${ }^{12}$ En efecto, entre los siglos XVI y XVIII, en Indias, tuvo lugar la recepción del derecho común o ius commune, por medio de la enseñanza universitaria y la circulación de la literatura jurídica, amén de su imbricación en el propio derecho regio.

Durante los siglos XVI, XVII y buena parte del XVIII, los juristas de temática indiana se adscribían al denominado mos italicus tardío. En la segunda mitad de la última centuria se aprecia una mayor preferencia por las citas al derecho real y a sus tratadistas o comentaristas.

Durante la Edad Moderna, la difusión de tratados y opiniones doctrinales diversas desembocó en la necesidad de preparar obras en lengua vernácula de carácter esencialmente pragmático, destinadas a facilitar el ejercicio profesional de los jueces, abogados y escribanos pertenecientes a las múltiples jurisdicciones. ${ }^{13}$ Un interesante ejemplo de biblioteca particular es la que formó Domingo de Arangoyti Peña, quien fue nombrado fiscal de la Real Audiencia de Guadalajara en Nueva Galicia. Después, fue el oidor más antiguo de la Real Audiencia de México, cargo que desempeñó hasta que falleció en Querétaro, en 1780. Entre sus volúmenes, contaba precisamente con una reimpresión madrileña del Cursus de Murillo Velarde. ${ }^{14}$

El doctor Alberto Carrillo señala que el Cursus gozó de prestigio, tanto en el ámbito de la docencia jurídica como en el de la práctica forense y pastoral. Desde el punto de vista formal, sigue la estructura de las canónicas Decretales de Gregorio IX. El importante manual de Murillo fue publicado en Madrid en 1743, y reimpreso en la misma urbe peninsular en 1763 y $1791 .^{15}$

\footnotetext{
${ }_{12}$ Martinez Martinez, Faustino, "lus commune, Utrumque ius: Tiempos de Derecho único, tiempos de juristas", Glossae. European Journal of Legal History, núm. 13, pp. 371-423. [Consulta: 10 de junio, 2017]. Disponible en: http://www. glossae.eu/wp-content/uploads/2016/11/Martinez-lus-commune.pdf

${ }^{13}$ BarRientos Grandón, JaVier, La cultura jurídica en la Nueva España (Sobre la recepción de la tradición jurídica europea en el virreinato), México, Instituto de Investigaciones Jurídicas de la Universidad Nacional Autónoma de México, 1993, pp. 12-108.

${ }^{14}$ Garcia, Idalla, "Libros de fiscal, libros de oidor: la biblioteca de Domingo de Arangoiti (siglo XVIII)", Investigación Bibliotecológica, vol. 26, núm. 57, pp. 13-76.

${ }^{15}$ Carrillo Cázares, Alberto, "Presentación" en Murillo Velarde, Pedro, Curso de derecho canónico hispano e indiano (edición de varios autores coordinada por Alberto Carrillo Cázares), Zamora - México D.F, El Colegio de Michoacán-Facultad de Derecho (UnAM), 2004, vol. I, libro primero, pp. 14-19.
} 


\section{Perfil biográfico y profesional de Pedro Murillo Velarde}

Pedro Murillo Velarde y Bravo nació en 1696 en la villa de Laujar de Andarax (en la actual provincia andaluza de Almería). Su abuelo, el licenciado Pedro Murillo Velarde López de Mayor, había contribuido en gran medida al ascenso social de la familia Murillo Velarde, al igual que sus dos hijos, Jacinto y Andrés. El primero, padre del jurista que protagoniza nuestro artículo, ejerció cargos civiles y participó en la Guerra de Sucesión a favor del aspirante Felipe. Por el contrario, el segundo siguió la carrera eclesiástica y llegó a ser obispo de Pamplona entre 1724 y 1728.

Como afirma el doctor Descalzo, Andrés desempeñó un papel fundamental en la trayectoria vital y académica de su sobrino antes de que ingresara en la Compañía de Jesús. ${ }^{16}$ Pedro Murillo inició su formación en esta orden mediante el paso por los colegios de Murcia y Toledo, donde estudió gramática y filosofía, amén de leer obras de historia y geografía. Adquirió una sólida formación como canonista en Granada y en Salamanca y aprendió filosofía y teología en el colegio jesuita de Alcalá de Henares. A la postre, desempeñó la docencia en las cátedras de cánones y leyes, concedidas a la primigenia Universidad de Filipinas, fundada por bula de Inocencio X y visada por la Audiencia de Manila en 1648. Desapareció por cédula de 1718, si bien la cédula de 26 de julio de 1730 dispuso la reinstauración de las cátedras de Instituta y de Sagrados Cánones: dos en el colegio de San Ignacio de los jesuitas de Manila y las otras dos en el colegio de Santo Tomás de la orden de predicadores.

Precisamente, la cátedra de Cánones para los jesuitas de Manila recayó en Murillo, por mandato de sus superiores, en 1745. Tras una serie de avatares, el religioso expiró en 1753, en el Puerto de Santa María, en la actual provincia española de Cádiz. ${ }^{17}$ Debemos señalar que, entre otros cargos, Murillo fue visitador de las misiones de Mindanao; redactó un manifiesto en favor de los indios de Gilán y San Mateo, así como un catecismo dirigido a la instrucción de los indígenas de Filipinas y algunos volúmenes sobre historia de la Compañía en el enclave asiático. ${ }^{18}$

Amén de su conocida y exitosa Práctica de testamentos, en su legado cultural, también destaca su Carta hydrographica y chorographica de las yslas

\footnotetext{
${ }^{16}$ Descalzo Yuste, Eduardo, La Compañia de Jesús en Filipinas (1581-1768): realidad y representación, Bellaterra, Universidad Autónoma de Barcelona, 2015, pp. 413-414, [Consulta: 10 de junio, 2017]. Disponible en: http://www. tdx.cat/handle/10803/323096

${ }^{17}$ Diaz de la Guardia y López, Luis, "Datos para una biografia del jurista Pedro Murillo Velarde y Bravo", Espacio, Tiempo y Forma, Historia Moderna, serie 4, núm. 14, pp. 407-471.

${ }^{18} \mathrm{Hanisch}$ Espindola, Hugo, "Pedro Murillo Velarde S. J., canonista del siglo XVIII", en VIII Congreso Internacional de Historia del Derecho Indiano, tomo 2, Madrid, Digibis Publicaciones Digitales, 2000, pp. 53-67.
} 
Filipinas. Asimismo, entre otros méritos de hondo calado intelectual, publicó la exhaustiva Geographia histórica, en diez volúmenes, cuya pretensión estribaba en la descripción del mundo conocido, su naturaleza y sus habitantes. ${ }^{19}$ En líneas generales, su Cursus vino constituido por la redacción de las lecciones que dictó en Manila. En el transcurso de aquellas clases, explicaba el derecho canónico, concordado con el derecho civil, el derecho real castellano y el derecho indiano. Tanto la doctrina como la práctica del derecho fueron abordadas en profundidad en los ámbitos espirituales y temporales. ${ }^{20}$

\section{Aspectos procesales y tipología delictiva en el Cursus de Murillo}

El propósito principal de este capítulo es el examen de los delitos y postulados procesuales contemplados en el Cursus de Pedro Murillo Velarde. Abordaremos fundamentalmente el libro $\mathrm{v}$, en virtud de su vertebración en torno al derecho criminal, y el título II del libro II, dedicado a los fueros o jurisdicciones. En este sentido, Murillo sostiene que la obtención del fuero deriva generalmente del domicilio, del contrato, del delito y de la ubicación de la cosa. Explica que la condición principal es el domicilio, donde el individuo sitúa a su familia y a sus bienes, con el ánimo de no abandonar el lugar, salvo impedimento.

Murillo toma de Gregorio López que el domicilio concurre con los otros fueros citados y es más importante, con excepción del fuero señorial. La persona, en consecuencia, tiene el fuero del domicilio, aunque el delito o el contrato hayan tenido lugar en otra parte o antes de que se hubiera avecindado. La pertenencia a un domicilio implicaba la sujeción a la jurisdicción del juez del lugar. El domicilio venía configurado por dos condiciones: el propósito de morar indefinidamente en la localidad, si no había ningún impedimento, así como el simple hecho de habitar allí. Asimismo, se estimaba que había intención de fijar el domicilio cuando la persona trasladaba a un lugar concreto la mayor parte de sus bienes o a toda su familia, o si permanecía allí al menos diez años.

En lo que respecta al ámbito doméstico, Murillo recordaba que la esposa y la viuda debían ser citadas en el lugar del domicilio del marido; el esclavo y el liberto e hijos, ante el juez del domicilio del dueño o del patrono, respectivamente. Los vagabundos sin domicilio conocido podían ser citados en cualquier lugar, aunque el delito se hubiera perpetrado en otro enclave.

\footnotetext{
${ }^{19}$ Descalzo Yuste, Eduardo, La Compañía de Jesús en Filipinas (1581-1768): realidad y representación, Bellaterra, Universidad Autónoma de Barcelona, 2015, pp. 416-420.

${ }^{20}$ Hanisch Espindola, Hugo, "Pedro Murillo Velarde S. J., canonista del siglo xVIII", en VIII Congreso Internacional de Historia del Derecho Indiano, tomo 2, Madrid, Digibis Publicaciones Digitales, 2000, p. 60.
} 
El jesuita contemplaba también el supuesto de los que moraban en un lugar durante buena parte del año con motivo de su ocupación, como los estudiantes universitarios, los embajadores, los siervos y los comerciantes. ${ }^{21}$ En el mismo capítulo, Murillo afirma que el reo queda sometido al juez del lugar en el que hubiera perpetrado el delito, ya fuera grave, leve, público o privado. Esta medida tendría cierto propósito disuasorio. No es de extrañar que los ladrones tristemente famosos hubieran sido ahorcados en los lugares donde habían delinquido. Por ende, la república herida o afectada por el crimen y la injuria debía recibir satisfacción mediante el castigo de los delincuentes que hubieran cometido sus crímenes en el territorio.

Además, desde una perspectiva práctica, en el lugar del delito se podría probar más fácilmente su comisión y se aplicaría la pena vigente en el lugar, ya fuera corporal o pecuniaria. Si el acusado huía del enclave, tras haber sido citado, el juez debía ordenar una nueva citación. Si era contumaz y no comparecía, el proceso continuaba y se señalaban sus bienes -era excomulgado en la esfera canónica-. En el supuesto de que la huida hubiera acaecido antes de la citación y se hallara en paradero desconocido, se debía hacer la información sumaria del delito, así como la citación por edicto, bien promulgada por el pregonero, o bien fijada por escrito a las puertas de la ciudad, del tribunal o de la iglesia, según el tipo de crimen.

En el supuesto de que el acusado, contumaz, no compareciera, no se le podría aplicar una pena corporal aflictiva. Sin embargo, sus bienes podrían ser ejecutados, incluso, si los tuviera en otro lugar, previo requerimiento al juez de aquel territorio. Asimismo, podría ocurrir que el juez conociera el paradero del delincuente, pero no podía aprehenderlo fuera de su jurisdicción, sino que debía proceder mediante cartas requisitorias. Si el delito era grave, el juez del lugar donde se hubiera perpetrado hacía una información sumaria, de modo que constara la identidad del autor. Incluía esta información en los documentos requisitorios y, a continuación, la remitía al juez del territorio en el que se encontrara el acusado.

En caso de que este segundo juez estuviera subordinado a otro "príncipe" o soberano, no estaba obligado a remitirle al reo. Empero, si ambos jueces estaban sujetos al mismo rey, el juez requerido quedaba compelido a capturar al delincuente y enviarlo al juez del domicilio o del delito, en virtud de su requerimiento. Además, estaba obligado a ejecutar la sentencia dada por el correspondiente juez, si era requerido para ello.

${ }^{21}$ Murillo Velarde, Pedro, Cursus juris canonici hispani et indicilCurso de derecho canónico hispano e indiano, Zamora - México, El Colegio de Michoacán - UNAM, 2008. 
Murillo explica que, en España, el juez requerido que no quería expedir al reo era castigado con la pena que merecía el delincuente. En contrapartida, el juez del lugar en el que estaba el reo podía enviarlo sin haber sido todavía requerido y, en consecuencia, sin estar aún obligado a ello. El delincuente sólo podía ser juzgado por el juez del domicilio, o del lugar del delito, pero no por el juez del territorio en el que se hubiera establecido. Este principio doctrinal no era óbice para que el juez del territorio en el que estuviera el reo debiera castigarlo a solicitud del acusador. Este último, a su vez, podía pedir que el reo fuera remitido al lugar del delito.

Por mor de la perspectiva casuista, Murillo plantea el supuesto de la persona herida que se desplazara y muriera en el límite entre dos territorios. En consecuencia, el acusado debía ser citado en el lugar en el que infligió la lesión, ya que allí iniciaría el proceso por homicidio. Si el individuo daba muerte a una persona que estaba en otro territorio, quedaba sujeto a esta última jurisdicción. También se procedía de esta manera si el acusado había ordenado perpetrar un homicidio en otro enclave. Sería juzgado en el lugar del crimen.

Amén de otros supuestos que podían suscitar dudas -como las competencias relativas a los cadáveres que yacieran en el propio confín de ambos territorios-, el jesuita aborda el destino de los que delinquieran en el mar o en una nave. En tal caso, tenían que ser capturados y enjuiciados por el juez competente del puerto más próximo. Empero, en las embarcaciones reales, el delincuente era castigado por el capitán bajo ciertas reglas. ${ }^{22}$

El libro v de la obra de Murillo contiene también algunos apartados dedicados a los herejes y, por lo tanto, a materias pertenecientes estrictamente a la jurisdicción del Santo Oficio, en el espacio hispánico. ${ }^{23}$ Sin embargo, en esta ocasión, nos decantaremos por la tipología delictiva en los ámbitos de la justicia secular y de la eclesiástica ordinaria.

El profesor jesuita aborda, por ejemplo, en el título x, los homicidios perpetrados en el seno de la familia, incluyendo los abortos -De His qui filios occiderunt-. Prosigue su discurso teórico acerca de la crueldad manifestada en el ámbito familiar, a través del título XI, dedicado a los infantes y enfermos abandonados -De Infantibus et Languidis expositis-. Alejándose del espacio doméstico, diserta acerca del homicidio voluntario o casual, en el título XII -De Homicidio voluntario, vel casuali-. Prosiguiendo en la amplia temática de las muertes violentas, el canonista andaluz dedica el muy sucinto título

\footnotetext{
${ }^{22}$ Murillo Velarde, Pedro, Cursus juris canonici hispani et indicilCurso de derecho canónico hispano e indiano, Zamora - México, El Colegio de Michoacán - unAm, 2008.

${ }^{23}$ Murillo Velarde, Pedro, Cursus juris canonici hispani et indicilCurso de derecho canónico hispano e indiano, Zamora - México, El Colegio de Michoacán - UNAM, 2008.
} 
XIII a los torneos -De Torneamentis-. Realmente, este epígrafe constituye el prolegómeno del título siguiente, dedicado a los individuos legos y religiosos que combatieran en duelo -De Clericis pugnantibus in duello-. ${ }^{24}$

Tras el título xv, dedicado a los buenos y malos usos de las armas en la guerra -De Sagitariis-, Murillo dedica su atención a los delitos contra la honestidad en el título xvI, analizando con especial atención el adulterio y el estupro. También se detiene en otros comportamientos como el concubinato, el incesto, las uniones sexuales de las personas pertenecientes al estamento eclesiástico y el pecado contra natura materializado en la bestialidad, la sodomía y la masturbación y otras conductas pecaminosas -De Adulteriis et stupro-. ${ }^{25}$ En este sentido, las prácticas contra natura fueron objeto de disquisiciones de carácter jurídico y moral durante la Edad Moderna, en un contexto de normativización de las manifestaciones de la sexualidad humana y de severa represión de los comportamientos que atentaran contra la unión heterosexual, procreadora y bendecida por el sacramento matrimonial.

Las aportaciones de Tomás y Valiente, así como de Clavero y Gacto han sido esclarecedoras en este sentido. Además, estudios recientes han profundizado en las consideraciones mayoritarias de los jueces sobre las mujeres acusadas del delito de sodomía, entre otras transgresiones morales. ${ }^{26}$ Precisamente, el examen de los crímenes contra la honestidad ha posibilitado la publicación de estudios especializados tendentes a la contextualización del anquilosado derecho positivo. Tal es el caso de las pesquisas concernientes a la punición del adulterio.

Los juristas del siglo xVIII, como Joseph Berni o Álvarez Posadilla, proporcionan información valiosa acerca de la evolución de la percepción social hacia la mujer acusada de adulterio, así como del desuso de las severas penas preceptuadas por el derecho regio. ${ }^{27}$

El título XVII comienza también en la línea temática de la lujuria, vertebrado en torno a comportamientos heterogéneos en su significación: el rapto de las mujeres, los incendios y la vulneración de la inmunidad del suelo sacro -De Raptoribus, Incendiariis et violatoribus Ecclesiarum-. ${ }^{28}$

\footnotetext{
${ }^{24}$ Murillo Velarde, Pedro, Cursus juris canonici hispani et indici/ Curso de derecho canónico hispano e indiano, Zamora - México, El Colegio de Michoacán - UnAM, 2008.

${ }^{25}$ Murillo Velarde, Pedro, Cursus juris canonici hispani et indicil Curso de derecho canónico hispano e indiano, Zamora - México, El Colegio de Michoacán - unam, 2008.

${ }^{26}$ Molina, Fernanda, "Juego de artificios. Prácticas jurídicas y estrategias judiciales frente al fenómeno de la sodomía en la España moderna", Prohistoria. Historia, políticas de la historia, año 18, núm. 24, pp. 43-68. [Consulta: 10 de junio, 2017]. Disponible en: http://www.scielo.org.ar/pdf/prohist/v24/v24a03.pdf

${ }^{27}$ Collantes de Terán, Maria José, "El delito de adulterio en el derecho general de Castilla", Anuario de historia del derecho español, núm. 66, pp. 222-223.

${ }^{28}$ Murillo Velarde, Pedro, Cursus juris canonici hispani et indicilCurso de derecho canónico hispano e indiano, Zamora - México, El Colegio de Michoacán - UNAM, 2008.
} 
No obstante, es necesario señalar que el título XLIX del libro III está dedicado específicamente a la inmunidad de los templos, cementerios y bienes muebles de carácter sagrado -De Immunitate Ecclesiarum, Caemeterii, et rerum ad eas pertinentium -. En este título, Murillo afirma que el principal privilegio derivado de la inmunidad del suelo religioso es el derecho de asilo de los reos. Especifica los casos y excepciones emanadas principalmente de la atrocidad de los delitos. Aborda con detalle las disposiciones canónicas sobre la inmunidad eclesiástica y las competencias jurisdiccionales de los jueces seculares y eclesiásticos sobre los delincuentes refugiados. ${ }^{29}$

En esta línea, las recientes pesquisas relativas al ejercicio de este derecho están proporcionando una valiosa información acerca de las fricciones jurisdiccionales en el siglo xvIII novohispano. La doctora López Ledesma ha observado -al menos en los tribunales potosinos de los siglos XVII y XVIIIque el asilo eclesiástico implicó la baja frecuencia en la aplicación de la pena capital. Asimismo, otros factores jurídicos, como el arbitrio judicial, las causas modificativas de la responsabilidad penal, el perdón de la víctima, el indulto y la minoría de edad. ${ }^{30}$

El título xviII del Cursus está dedicado a los hurtos -De Furtis-.${ }^{31}$ Es importante tener en cuenta que los juristas castellanos sostuvieron opiniones diversas en cuanto a los delitos contra la propiedad, si bien es cierto que fue nítida la distinción entre el hurto, el robo y el abigeato. No obstante, en el ámbito de los tribunales inferiores peninsulares y novohispanos, se aprecia una precisión menor en la identificación de la categoría penal concreta, como ha demostrado la doctora García León. ${ }^{32}$

En lo que atañe a la apropiación ilícita de bienes, también es interesante el título XIx, relativo a las prácticas que implicaban usura -De Usuris-. A su vez, el título xx está vertebrado en torno al crimen de falsedad-De Crimine Falsi-. En el título XXI -De Sortilegiis-, el autor analiza los sortilegios, pero exalta el buen uso de las ciencias y la observación de la naturaleza. Además, contempla los supuestos en los cuales el sortilegio y la magia son competencia de la jurisdicción secular. Tal es el caso de las brujas y hechiceras que hubieran perpetrado numerosos infanticidios.

\footnotetext{
${ }^{29}$ Murillo Velarde, Pedro, Cursus juris canonici hispani et indicilCurso de derecho canónico hispano e indiano, Zamora - México, El Colegio de Michoacán - unam, 2008.

${ }^{30}$ López Ledesma, Adriana, "La inmunidad eclesiástica en la Alcaldía Mayor de San Luis Potosí: ¿Un enfrentamiento entre fueros?", Cuadernos de Historia del Derecho, vol. extraordinario, 2010, pp. 255-276.

${ }^{31}$ Murillo Velarde, Pedro, Cursus juris canonici hispani et indicilCurso de derecho canónico hispano e indiano, Zamora - México, El Colegio de Michoacán - UnAM, 2008.

${ }^{32}$ Garcí León, Susana, "Los delitos contra la propiedad: el empleo inadecuado de la terminología penal por parte de los operadores jurídicos durante la Edad Moderna", Clio \&t Crimen, núm. 11, 2014, pp. 23-38.
} 
Para el conocimiento de la actividad procesal cotidiana es de particular interés el sucinto título xxII, vertebrado sobre la colusión, convenio fraudulento entre el actor y el reo que conllevaba la impunidad de los delitos -De Collusione detegenda-. El profesor jesuita prosigue su disertación jurídica, entrando en el ámbito de las circunstancias personales del delincuente. Aborda, en este sentido, la comisión de los crímenes por parte de los niños en el título XXIII -De Delictis puerorum-. ${ }^{33}$ El examen del ordenamiento jurídico castellano, y de las opiniones de juristas como el reputado Gregorio López, posibilita apreciar la trascendencia de la menor edad en la valoración y aplicación de la pena a los reos. ${ }^{34}$

El título xxIV está dedicado específicamente al clérigo cazador -De Clerico Venatore-y el título xxv, relativo al clérigo percusor -De Clerico percussore-. En relación con las actividades cinegéticas, el profesor explica detalladamente las circunstancias en las que está prohibida la caza, así como las razones que subyacen en las normas. En lo que atañe a los clérigos, establece distinciones en función de la actividad, el tipo de presa capturada y del régimen de las órdenes religiosas. Define con nitidez los supuestos lícitos e ilícitos. Más que de privilegios en la sanción, el autor escribió este título con el fin de esclarecer si la obtención de peces, caza menor y mayor, por parte de los religiosos, era moralmente admisible. El breve epígrafe sobre el clérigo percusor profundiza, por otra parte, en el uso y abuso del castigo físico que empleaban los clérigos contra los seglares y religiosos. En todo caso, el jesuita contempla la costumbre y licitud de la punición de los religiosos delincuentes por parte del brazo secular.

No podemos obviar que la aplicación de las penas a los religiosos que delinquían constituye un tema abordado por Pedro Murillo en diferentes apartados de su voluminoso Cursus, amén del susodicho libro quinto. En este sentido, son reseñables sus acotaciones contenidas en el libro segundo, título II, De foro competente. ${ }^{35}$ Centrémonos a continuación en las peculiaridades inherentes al enjuiciamiento de los delincuentes religiosos y de otras personas que gozaban de un fuero especial.

Murillo explica que los clérigos debían ser demandados en las esferas civil y penal ante su obispo o juez correspondiente, salvo algunas excepciones. El obispo competente era el del domicilio o del lugar del delito perpetrado.

${ }^{33}$ Murillo Velarde, Pedro, Cursus juris canonici hispani et indicilCurso de derecho canónico hispano e indiano, Zamora - México, El Colegio de Michoacán - UnAM, 2008.

${ }^{34}$ Martinez Gujón, José, "La menor edad en el Derecho penal castellano-leonés anterior a la codificación", Anuario de historia del derecho español, núm. 44, pp. 465-483.

${ }^{35}$ Murillo Velarde, Pedro, Cursus juris canonici hispani et indicil Curso de derecho canónico hispano e indiano, Zamora - México, El Colegio de Michoacán - UnAM, 2008. 
En un orden superior, los obispos implicados en causas criminales complejas eran denunciados ante el romano pontífice. Las causas criminales menores de los obispos se resolvían, por el contrario, en el concilio provincial.

Podía darse la circunstancia de que un seglar delinquiera y con posterioridad se hiciera clérigo. Si el inicio de la causa tenía lugar tras este cambio de estado, el juicio debía celebrarse ante la justicia eclesiástica. En el caso de que ya lo hubiera iniciado el juez secular, mediante la citación o por la interposición de la querella, la justicia ordinaria proseguía lícitamente sus actuaciones. Sin embargo, el delincuente no era castigado con pena corporal aflictiva, porque era persona exenta, pero sí podía recibir una pena pecuniaria o sufrir la confiscación de sus bienes.

Por el contrario, podía darse el supuesto de que un fraile delinquiera y después retornara al estado lego, bien para contraer matrimonio, o bien por haber sido expulsado de su orden religiosa. Ante esta circunstancia, era castigado por el juez eclesiástico, pues se atendía al estado que tenía el delincuente en el momento en que cometió el delito. Este privilegio clerical no podía ser renunciado por ningún religioso en particular, ni tácita ni expresamente, ni por juramento añadido, ya fuera en causa espiritual, criminal o civil. La razón de esta medida era que el derecho público no podía ser alterado por un pacto entre particulares.

Murillo afırma que tanto la jurisdicción eclesiástica como la real deben funcionar sin intromisiones externas. En este sentido, asevera que, cuando un clérigo y un lego eran aliados en el mismo crimen, no siendo un delito eclesiástico o de fuero mixto, cada uno debía ser castigado por su propio juez. En esta línea, el derecho real español prohibía que los legos fueran llevados ante el juez eclesiástico en una causa secular.

El título XXXIII está dedicado específicamente a los privilegios y sus límites -De Privilegiis et excesibus Privilegiatorum-. El autor centra su explicación en los actos de concesión, cese y revocación de los privilegios a los individuos o comunidades, por mandato de los príncipes, reyes y pontífices. En todo caso, el libro $v$ menciona las penas aplicables a los clérigos que perpetraran delitos, incidiendo en la competencia jurisdiccional relativa a su punición. ${ }^{36}$

Los religiosos no constituían el único colectivo que gozaba de un fuero privilegiado. En efecto, el profesor jesuita aborda las especificidades relativas a los individuos exentos del fuero ordinario: los militares, los estudiantes, las personas “miserables” y los familiares de la Inquisición. A modo de ejemplo,

${ }^{36}$ Murillo Velarde, Pedro, Cursus juris canonici hispani et indicilCurso de derecho canónico hispano e indiano, Zamora - México, El Colegio de Michoacán - UNAM, 2008. 
señalemos que los rectores de las universidades de Lima y de México conocían las causas de los escolares y de los profesores en las esferas civil y criminal -a excepción de las que implicaran penas corporales-, siempre y cuando tuvieran conexión con el espacio universitario. De lo contrario, eran competentes los jueces ordinarios. En general no gozaban del fuero privilegiado los individuos no estudiantes que delinquían, eran citados por un juez y después ingresaban en una universidad. ${ }^{37}$

A continuación de los susodichos títulos XXIV y xxv, Murillo retoma el hilo de sus explicaciones respecto a las características de los comportamientos pecaminosos y los delitos. Así, construye el título XXVI sobre la significación de las maldiciones y blasfemias -De Maledicis-, si bien no obvia las sanciones que el derecho real hispano impone a las personas que injurian y dirigen graves insultos a otras.

Tras otros títulos relativos exclusivamente a los delitos cometidos en el seno de la Iglesia, el jesuita dedica el título xxxII a los supuestos de edificaciones ilícitas, consideradas como tal por las ordenanzas locales y el bien público y de la vecindad, entre otros motivos -De novi operis Nuntiatione-. El título XXXIV aborda la purgación canónica -De Purgatione Canonica-, que el autor define como la demostración de la inocencia respecto al delito y de conformidad de los sagrados cánones.

La disertación acerca de las antiguas prácticas ya desaparecidas constituye, una vez más, una estrategia didáctica que demuestra nítidamente la transformación de la praxis jurídica. No en vano, en el título xxxv, relativo a la purgación vulgar -De Purgatione vulgari- Murillo vuelve a incidir en las vetustas creencias vinculadas a las ordalías.

El legado jurídico romano es la piedra angular sobre la cual se erige el título xxxvI, dedicado a las injurias y al daño -De Injuriis et damno dato-. No obstante, la concepción de injuria que esgrime el autor a lo largo del título es la de delito privado perpetrado con dolo y en contumelia de otra persona, y menoscabo de su honra frente a los demás. En lo que concierne al daño, podría hacerse con dolo, con culpa, o bien por caso fortuito. Por otra parte, el profesor jesuita esgrime hábilmente la doctrina y la bibliografía pragmática, para proporcionar las soluciones necesarias ante las vicisitudes comunes en su época, como los daños ocasionados con motivo de un naufragio. ${ }^{38}$

\footnotetext{
${ }^{37}$ Murillo Velarde, Pedro, Cursus juris canonici hispani et indicilCurso de derecho canónico hispano e indiano, Zamora - México, El Colegio de Michoacán - UnAm, 2008.

${ }^{38}$ Murillo Velarde, Pedro, Cursus juris canonici hispani et indicilCurso de derecho canónico hispano e indiano, Zamora - México, El Colegio de Michoacán - UNAM, 2008.
} 
El título xxxviI, vertebrado en torno a las penas -De Poenis-, parte fundamentalmente del derecho romano clásico. Trata su aplicación en el marco de la jurisdicción eclesiástica y los preceptos de la Recopilación de leyes de los reinos de las Indias, sin obviar las referencias a las opiniones de los autores. Desde un sentido amplio, la pena abarcaba las penas medicinales, las civiles y las vindicativas. Estas últimas serían las penas en sentido estricto y provienen de la potestad pública que tiene la autoridad de castigar con un fin honesto. Éste es la enmienda del delincuente o al menos la función ejemplarizante. Ha de guardarse la proporción aritmética y equidad de la pena con la culpa, como corresponde en los actos de la justicia conmutativa. No obstante, deben atenderse las circunstancias de los delincuentes.

Murillo también define las penas capitales, ordinarias, extraordinarias y arbitrarias. Las extraordinarias y arbitrarias no se ordenan por el derecho o la costumbre, sino por el arbitrio del juez, por mor de las circunstancias del delito, de la persona, del lugar y del tiempo, entre otros factores. ${ }^{39}$ Es importante tener en cuenta el orden jurídico del ius proprium, relativo al texto de la ley y al arbitrio judicial, así como la supletoriedad del ius commune, en la interpretación del derecho criminal de la Edad Moderna.

Como ha señalado el doctor Álvarez Cora, la qualitis delicti era un factor fundamental en la apreciación del crimen. ${ }^{40} \mathrm{Al}$ mismo tiempo, recientes pesquisas del doctor Ortego han profundizado en la absolución, para diferenciar la libre absolución de la absolución de la instancia. Esta última, sustentada por la doctrina, implicaba la conclusión del juicio cuando no existían pruebas, sino sólo sospechas de la comisión del delito. Pero, la absolución de instancia también posibilitaba el inicio de otro proceso sobre los mismos hechos perpetrados, al no producirse el efecto de cosa juzgada. ${ }^{41}$

A modo de colofón de este extenso título, el canonista andaluz incluye un glosario de delitos en orden alfabético, acompañados de sus respectivas penas. Estas últimas están caracterizadas frecuentemente por la discrecionalidad judicial $\mathrm{y}$, en ocasiones, por la costumbre, tendente a la mitigación de la severidad en los castigos. Al mismo tiempo, Murillo refleja algunas especificidades indianas en la sanción de los delitos, como la competencia jurisdiccional sobre los

\footnotetext{
${ }^{39}$ Murillo Velarde, Pedro, Cursus juris canonici hispani et indicilCurso de derecho canónico hispano e indiano, Zamora - México, El Colegio de Michoacán - UNAM, 2008.

${ }^{40}$ Álvarez Cora, Enrioue, "Tipicidad y fragmentariedad criminal en la España moderna", Cuadernos de Historia del Derecho, núm. 20, pp. 207-233.

${ }^{41}$ Ortego GlL, Pedro, "Innocentia praesumpta: absoluciones en el Antiguo Régimen", Cuadernos de Historia del Derecho, núm. 10, pp. 71-125.
} 
indios que practicaban la adivinación. ${ }^{42}$ El tratamiento jurídico de los pobladores naturales de América, ora como reos, ora como víctimas de crímenes y de prácticas abusivas, constituyó un aspecto de crucial importancia en la literatura jurídica indiana. Así lo pusieron de manifiesto Avendaño y otros autores de la Edad Moderna temprana. ${ }^{43}$

Las conductas indexadas, que incluían algunas conocidas por la jurisdicción inquisitorial de modo privativo y otras por la jurisdicción eclesiástica ordinaria, son: ${ }^{44}$ el abigeato - robo de ganado-, el aborto, la regatonería, la adivinación, el adulterio, el conato de delito, el lenocinio, la falsificación de escrituras, la apostasía, el asesinato, la bigamia, la blasfemia, la bofetada, la cacería ilegal, la calumnia, la falsificación del nombre, el quebrantamiento y huida de la cárcel, el establecimiento de una cárcel privada y consiguientes encarcelamientos ilícitos, el castigo inmoderado contra los siervos e hijos, la castración, la exposición ambulante de animales, los coitos ilícitos, el concubinato, la delación, la difamación, los malos usos del disfraz, batirse en duelo, la embriaguez, el encubrimiento de los delincuentes, recurrir a trucos con el fin de robar o engañar a un cliente, el monopolio ilícito, el estelionato o crimen sin denominación específica y cometido con dolo, el estupro, la evasión de tributos, la exposición o abandono de niños, la falsificación de documentos, el falso testimonio, la hechicería, la herejía, el robo de herencia, el homicidio, el hurto, el incendio intencionado, el incesto, la injuria, la vulneración del asilo eclesiástico, la intriga o entrega de dinero con el fin de obtener una dignidad $u$ honor, los juegos ilegales, el robo de viviendas, la liberación ilícita de presos, el desplazamiento ilegal de los mojones, el maleficio, la mendicidad, la acuñación de moneda falsa o su adulteración, el parricidio, el parto fingido, el peculado o hurto de dinero público o sagrado, el perjurio promisorio y el asertorio, el plagiario o venta y compra de una persona libre, la prevaricación, la quiebra fraudulenta de los cambistas o banqueros, la rapiña o hurto violento, el rapto de mujeres, el sacrilegio, el asalto o robo en vías públicas, la revelación del secreto de la confesión sacramental, la simonía, el soborno y otros delitos cometidos por los jueces, la sodomía, el sortilegio, el suicidio, la tala ilegal, la traición de lesa majestad, la usura, el envenenamiento intencionado, el ejercicio de la violencia y la violación de sepulcro.

\footnotetext{
${ }^{42}$ Murillo Velarde, Pedro, Cursus juris canonici hispani et indicilCurso de derecho canónico hispano e indiano, Zamora - México, El Colegio de Michoacán - UnAM, 2008.

${ }^{43}$ Cuena Boy, Francisco José, "El castigo de las injurias causadas a los indios. Una página característica de Diego de Avendaño", Cuadernos de Historia del Derecho, núm. 19, pp. 9-25.

${ }^{44}$ Murillo Velarde, Pedro, Cursus juris canonici hispani et indicil Curso de derecho canónico hispano e indiano, Zamora - México, El Colegio de Michoacán - Unam, 2008.
} 
En el glosario, Murillo contempla la significación de la excomunión y la penitencia impuesta por la Inquisición, al igual que algunas circunstancias especiales relativas a los reos, como la locura, el sonambulismo, la pertenencia al pueblo gitano, $\mathrm{y}$, fundamentalmente, la condición de los indios o la comisión de los delitos en las Indias. Empero, el examen de las penas establecidas en este glosario ha de ser complementado con la consulta de los estudios históricojurídicos que, desde hace décadas, han incidido en los delitos contemplados por el derecho positivo del antiguo régimen, como la falsificación de documentos (regios, pontificios y notariales) ${ }^{45}$ y monedas. $^{46}$

Los iushistoriadores han profundizado también en la configuración histórica y jurídica de las penas aplicadas en la Edad Moderna, tales como la confiscación de bienes ${ }^{47}$ y el exilio. ${ }^{48} \mathrm{Al}$ respecto, la doctora Ramos Vázquez ${ }^{49}$ ha efectuado exitosamente el estudio de la cárcel como medida cautelar o coactiva en el procedimiento criminal del antiguo régimen, y de los antecedentes de su construcción jurídica como pena privativa de libertad.

Algunas pesquisas sobre las actividades ilícitas económicas en Nueva España han subrayado la transformación del pensamiento económico en el siglo xvIII. De este modo, proporcionan una interpretación acerca de las prohibiciones normativas desde el contexto político y social. ${ }^{50}$ Algunas contribuciones recientes han incidido en la aplicación del tormento judicial en los procesos criminales novohispanos y en la importancia de los formularios criminales en la instrucción procesual en el ámbito de la justicia local. Asimismo, han demostrado la equiparación entre los indios y los menores de edad en la esfera forense. ${ }^{51}$

El profesor jesuita concluye el libro $\mathrm{v}$ abordando las penitencias y remisiones en el título xxxvIII, que incluye un epígrafe dedicado a las indulgencias apócrifas, al igual que las sentencias de excomunión, suspensión y entredicho, en el título XxxIx. ${ }^{52}$

${ }^{45}$ Alejandre Garcia, Juan Antonio, "Estudio histórico del delito de falsedad documental", Anuario de historia del derecho español, núm. 42, pp. 117-187.

${ }^{46}$ Salnz Guerra, Juan, "Moneda y delincuencia: siglos xVI al xvII", Anuario de historia del derecho español, vol. 2, núm. 67, pp. 1619-1630.

${ }^{47}$ Pino Abad, Miguel, La pena de confiscación de bienes en el derecho histórico español, Córdoba, Universidad de Córdoba, 1999.

${ }^{48}$ Torres Aguilar, Manuel, "La pena de exilio: sus origenes en el derecho romano", Anuario de historia del derecho español, núm. 63-64, pp. 701-786.

${ }^{49}$ Ramos Vázouez, Isabel, "Detenciones cautelares, coactivas o punitivas. La privación de libertad en el derecho castellano como instrumento jurídico", Anuario de historia del derecho español, núm. 77, 707-770.

${ }^{50}$ Martinez de Vega, Maria Elisa, "Los mercaderes novohispanos: control virreinal y fraude fiscal en el primer tercio del siglo xvı", Revista Complutense de Historia de América, núm. 20, pp. 87-128.

${ }^{51}$ Garcia León, Susana, "La aplicación del tormento judicial en la Nueva España. El ejemplo de tres pleitos sustanciados en la Mixteca Alta durante el siglo XVII", Cuadernos de Historia del Derecho, vol. extraordinario, 2010, pp. 129-145.

${ }^{52}$ Murillo Velarde, Pedro, Cursus juris canonici hispani et indicil Curso de derecho canónico hispano e indiano, Zamora - México, El Colegio de Michoacán - UNAM, 2008. 


\section{Las fuentes del derecho en el Cursus}

Básicamente, el Cursus se sustenta en el derecho romano clásico, el derecho canónico, el derecho real indiano y castellano, la doctrina de los autores, la tratadística gubernativa y judicial indiana y, en menor medida, la costumbre. Respecto al derecho real, la Recopilación de Indias y la Nueva Recopilación de Castilla son referencias fundamentales del curso.

El doctor Carrillo Cázares ha advertido que el manual es prolijo en citas tomadas del Corpus Iuris Canonici y del justinianeo Corpus Iuris Civilis. Mientras, en lo que atañe a la normativa hispánica, son especialmente frecuentes las menciones a las Partidas, el Fuero Juzgo, el Fuero Real, las Leyes de Toro, así como a las recopilaciones mencionadas. El profesor jesuita, pese a escribir su obra en latín, incluyó las citas procedentes de las disposiciones del derecho real en lengua española. ${ }^{53}$

En lo que atañe a las normas romanas en el ámbito criminal, destacan sus referencias a la Lex Aquilia, la Lex Cornelia de sicariis et veneficis, las penas del senadoconsulto Turpiliano, la Lex Remmia de Calumniatoribus, la Lex Pompeia de parricidiis, la Lex Iulia de Adulteris Coercendis, la Lex Flavia de Plagiariis y la Lex Cornelia de Falsis.

Es necesario tener en cuenta que los estudios universitarios de derecho civil y de derecho canónico implicaban la asistencia de los alumnos a lecciones sobre pasajes de las Instituciones, el Código y el Digesto. Los estudios de derecho civil abordaban el comentario y la explicación de textos y glosas del Corpus. Los de derecho canónico versaban esencialmente sobre el Decreto, las Decretales, el Sexto y las Clementinas. No obstante, desde mediados del siglo XV, profesores, como el canonista Juan Alfonso de Benavente, habían insistido en el conocimiento del derecho regio. En consecuencia, era fundamental relacionar el Decreto y las Decretales con las posteriores normas canónicas, así como el derecho romano clásico con el Fuero Real, las Partidas y otras importantes disposiciones reales. ${ }^{54}$

En lo concerniente a los autores y obras sobre los delitos, las herejías y la práctica procesal, el jesuita incluye citas de Praxis ecclesiasticae et secularis, de Gonzalo Suárez de Paz; De iustitia et iure, de Luis de Molina; los ineludibles comentarios a las Partidas, de Gregorio López; el Juris Ecclesiastici, de Agostinho Barbosa; Disquisitionum magicarum libri sex, de Martín del Río;

\footnotetext{
${ }^{53}$ Carrillo Cazares, Alberto, "Presentación" en Pedro Murillo Velarde, Curso de derecho canónico hispano e indiano, Zamora - México, El Colegio de Michoacán - UNAM, 2004, pp. 20-22.

${ }^{54}$ Alonso Romero, María Paz, Salamanca, escuela de juristas. Estudios sobre la enseñanza del derecho en el Antiguo Régimen, Madrid, Universidad Carlos III - Dykinson, 2012, pp. 175-176.
} 
De Arbitrariis iudicum de Menocchio, Practicarum quaestionum, de Diego Covarrubias; Tractatus de Casibus Curiae, de Francisco Carrasco del Saz; la Política, de Castillo de Bobadilla; la Curia, de Hevia Bolaños; De Indiarum iure y Politica indiana, de Juan de Solórzano Pereira; De justitia et jure, del jesuita Juan de Lugo; la Praxis et theoricae criminalis, de Prospero Farinacci; De justitia et jure, del dominico, Domingo de Soto; De justitia et Iure, del jesuita flamenco, Leonardus Lessius, y De legibus, del jurista y teólogo jesuita, Francisco Suárez, entre otros volúmenes y autores.

Además, aparecen referencias, menos precisas, a Giulio Claro; Antonio Gómez; Bartolo da Sassoferrato; el docto criollo, Alloza; el doctor Navarro (Martín de Azpilcueta), y el jesuita austriaco, Laymann, entre otros. En resumen, si bien es cierto que es notoria la presencia de teólogos, filósofos y juristas pertenecientes a su misma orden religiosa, también son frecuentes las citas a los autores de otras órdenes y a los laicos más prestigiosos en el campo del derecho criminal, de la práctica judicial y del gobierno y justicia en Indias.

Murillo agrega también referencias a personalidades trascendentales en la historia del pensamiento teológico, como San Antonino, Agustín de Hipona, San Buenaventura, San Gregorio y Tomás de Aquino. Para amenizar la árida disertación, recurre ocasionalmente a bellísimos pasajes de la literatura grecolatina, como La Eneida y las Geórgicas de Virgilio. Amén de las definiciones de Nebrija, toma acepciones del Diccionario de Trévoux y de Francisco Sobrino. Los ejemplos extraídos de los diversos libros que conforman el Antiguo y el Nuevo Testamento y los sucesos aciagos de épocas pasadas también desempeñan un papel relevante en el discurso jurídico y moral de Pedro Murillo. Así, se asemeja a las didácticas explicaciones procedentes del legado romano.

\section{Conclusiones}

El Cursus de Pedro Murillo ha de ser examinado, en virtud de los parámetros de la docencia legal de la primera mitad del siglo xviII. El legado romano clásico está presente en las explicaciones sobre las conductas delictivas. Sin embargo, Murillo no se limita a citar disposiciones normativas, originarias de los horizontes culturales romano y medieval. En numerosas ocasiones, se detiene en la desaparición de algunas vetustas prácticas jurídicas, así como en la etimología de determinados vocablos y la transformación de su significado en la práctica procesal.

El proceder de Murillo no es una mera manifestación erudita, sino una estrategia didáctica, orientada a la formación de los estudiantes de leyes. El empleo del latín en la redacción de la obra hace posible una explicación más 
prolija acerca de los delitos "contra la honestidad" y los pecados de índole sexual. Mujeres, hombres y niños eran potenciales víctimas de este tipo de abusos, como claramente se deduce de la exposición teórica del profesor jesuita.

La formación teológica del autor se manifiesta ampliamente en sus consideraciones acerca de la venialidad o gravedad de los pecados en que el delincuente cayera. Sin embargo, en sus epígrafes, podemos apreciar la distinción entre las ofensas a la religión y los comportamientos delictivos que merecían la punición por mor del derecho real. Por esta razón sería incorrecto achacar a Murillo la identificación absoluta del delito con el pecado. La importancia que el autor otorga al derecho canónico en el manual no impide que el autor conozca en profundidad el derecho real aplicado en Indias y en la península. Sus exposiciones acerca de las transgresiones son fundamentales para comprender las competencias privativas de los jueces inquisitoriales y las especificidades indianas relativas a esta última jurisdicción.

A priori, el individuo perteneciente al estamento eclesiástico recibe un tratamiento jurídico diferente al que se otorga a los seglares. Empero, cuando Murillo analiza cada una de las conductas heterodoxas, hace hincapié en la necesidad de que los religiosos lleven una vida ejemplar y regida por la moral cristiana. En esta línea, el jesuita contribuye a la construcción teórica del ideal de religioso secular o regular, pío y justo en sus funciones y procederes. Además, no se limita a ofrecer pautas de conducta y ejercicio profesional en el espacio eclesiástico del cabildo catedralicio, el convento, la provincia religiosa o la arquidiócesis. Hábilmente, define cuáles han de ser los comportamientos idóneos en el exterior y ante la comunidad lega.

En este sentido, sus consejos guardan cierta similitud con los que mucho tiempo atrás había redactado Castillo de Bobadilla, en su archiconocida Política, en la que esgrimía las características morales, e incluso físicas, que debía reunir el individuo que impartía justicia, ya fuera lego o religioso. Murillo definía un modo justo de vivir y proceder, ajeno a la tentación de incurrir en prácticas abusivas y en pretensiones de absoluta impunidad.

Desde un punto de vista metodológico, el manual se circunscribe a la perspectiva casuista. La exposición de los casos posibles relativos a la comisión y circunstancias de cada delito, así como la inclusión de opiniones doctrinales contrapuestas son dos características que imperaron en la literatura jurídica hispana de los siglos XVI y XVII. Tales rasgos influyeron profundamente en la redacción de la extensa obra y contrastaron con la posterior síntesis que realizaron los profesores aragoneses, Ignacio Jordán y Miguel de Manuel, en su manual Instituciones del derecho civil de Castilla. En éste, primaba la explicación del derecho real en detrimento del resto de las fuentes jurídicas. 
Desde la perspectiva procesal, el jesuita contribuye a la persistencia de la Curia, de Hevia Bolaños, como referencia bibliográfica fundamental para el aprendizaje de la práctica judicial en los tribunales reales y eclesiásticos del siglo xvIII. No en vano esta fuente, que consultó con tanta atención, sería objeto de una nueva impresión en 1790, auspiciada por el propio Consejo de Castilla y con enmiendas y correcciones efectuadas por el abogado Juan Martín de Villanueva.

Pese a vivir en siglos diferentes y poseer perfiles profesionales de diverso cariz, Hevia y Murillo tienen en común la experiencia vital en Indias. Ambos autores contribuyeron a la difusión de los fundamentos de los procesos civiles y criminales desarrollados ante los jueces legos y eclesiásticos ordinarios. Al mismo tiempo, el jesuita incluye pertinentes alusiones al tratamiento jurídico otorgado a los indígenas acusados de determinados delitos.

El Cursus, por tanto, es una fuente necesaria en las pesquisas relativas a la práctica judicial en Iberoamérica, antes de los procesos emancipadores. Si bien la trayectoria indiana de su autor tuvo lugar en el periférico espacio filipino, sus explicaciones casuísticas no se circunscriben de manera especial a las particularidades administrativas, sociales y étnicas del archipiélago, sino que abarcan el espacio global de la monarquía. Sus páginas reflejan indudablemente la solidez de sus conocimientos jurídicos y teológicos, al igual que su experiencia docente.

Sin ambages, podemos afirmar que la referida obra es una contribución fundamental para la historia de la enseñanza de los dos derechos en el antiguo régimen. Está destinada de manera primordial a la formación jurídica y no obvia las referencias a títulos de corte pragmático y en lengua vernácula. Esta característica del Cursus nos permite apreciar las conexiones entre los diversos géneros jurídicos de la época, pese a que su cultivo obedeciera a propósitos diferentes y tuviera como receptores a lectores de heterogénea formación o posición en las instituciones legas y religiosas.

En síntesis, estamos en condiciones de afirmar que el monumental curso de Murillo no es una mera disertación acerca del derecho positivo. Está alejado del criterio legalista, esgrimido sobre todo por reputados juristas del siglo XVIII, en lo que concierne al ámbito penal, e impulsado con éxito en la época contemporánea, merced al fenómeno codificador. Pese a que la norma promulgada constituye un pilar teórico del libro analizado, su autor nos proporciona valiosa información acerca del poder de la costumbre en el ejercicio de la actividad judicial penal. Tal fuente jurídica, tradicionalmente, no ha suscitado tanta atención entre los historiadores del derecho criminal de la monarquía absoluta. En contraste, han tenido mayor interés por el derecho positivo, los principales autores del pensamiento escolástico tardío y, finalmente, por el 
funcionamiento y los agentes del proceso penal en las diversas regiones del mundo iberoamericano.

En suma, las costumbres vigentes en la época de la redacción del manual permiten entrever una evolución de la práctica judicial criminal, a lo largo del antiguo régimen. A modo de conclusión, el Cursus de Murillo Velarde invita a profundizar en la significación de las diversas fuentes del derecho en la enseñanza jurídica de gran parte del siglo xvIII y, de manera especial, en las transformaciones que habían tenido lugar en la práctica procesal indiana y peninsular. En sus explicaciones, logra conciliar la tradición romanista con las observaciones concernientes a las cuestiones generadas en el ámbito colonial. No menor importancia tendrá el atento estudio de la presencia de los más reputados juristas de la temprana Edad Moderna en la exposición teórica del profesor jesuita.

\section{Bibliografía}

Alejandre García, Juan Antonio, "Estudio histórico del delito de falsedad documental", Anuario de historia del derecho español, núm. 42, pp. 117-187.

Alonso Romero, María Paz, Francisco Tomás y Valiente. Memoria y legado de un maestro, Salamanca, Ediciones Universidad de Salamanca, 2016.

Alonso Romero, María Paz, Salamanca, escuela de juristas. Estudios sobre la enseñanza del derecho en el Antiguo Régimen, Madrid, Universidad Carlos III - Dykinson, 2012. Alonso Romero, Marí PAz, El proceso penal en Castilla (siglos XIII-XVIII), Salamanca, Universidad de Salamanca - Diputación Provincial de Salamanca, 1982.

Álvarez Cora, Enrique, “Tipicidad y fragmentariedad criminal en la España moderna”, Cuadernos de Historia del Derecho, Universidad Complutense de Madrid, No. 20, 2013, pp. 207-233.

BARRIENTOS GRANDón, Javier, La cultura jurídica en la Nueva España (Sobre la recepción de la tradición jurídica europea en el virreinato), México, Instituto de Investigaciones Jurídicas de la Universidad Nacional Autónoma de México, 1993.

Carrillo CÁzares, Alberto, "Presentación" en Pedro Murillo Velarde, Curso de derecho canónico hispano e indiano, Zamora - México, El Colegio de Michoacán - unAm, 2004.

Collantes de Terán, María José, "El delito de adulterio en el derecho general de Castilla", Anuario de historia del derecho español, núm. 66.

Cuena Boy, Francisco José, "El castigo de las injurias causadas a los indios. Una página característica de Diego de Avendaño”, Cuadernos de Historia del Derecho, núm. 19. Descalzo Yuste, Eduardo, La Compañia de Jesús en Filipinas (1581-1768): realidad y representación, Bellaterra, Universidad Autónoma de Barcelona, 2015. [Consulta: 10 de junio, 2017]. Disponible en: http://www.tdx.cat/handle/10803/323096 
Díaz de la Guardia y LóPez, Luis, "Datos para una biografía del jurista Pedro Murillo

Velarde y Bravo”, Espacio, Tiempo y Forma, Historia Moderna, serie 4, núm. 14. Fiestas LozA, Alicia, "Francisco Tomás y Valiente y la historia del derecho penal”, en

María Paz Alonso Romero (ed.), Francisco Tomás y Valiente. Memoria y legado de un maestro, Salamanca, Ediciones Universidad de Salamanca, 2016.

García, IdAlia, "Libros de fiscal, libros de oidor: la biblioteca de Domingo de Arangoiti (siglo XVIII)”, Investigación Bibliotecológica, vol. 26, núm. 57.

García León, SusAnA, "Los delitos contra la propiedad: el empleo inadecuado de la terminología penal por parte de los operadores jurídicos durante la Edad Moderna”, Clío \&t Crimen, núm. 11, 2014.

García León, SusAnA, "La aplicación del tormento judicial en la Nueva España. El ejemplo de tres pleitos sustanciados en la Mixteca Alta durante el siglo XVII", Cuadernos de Historia del Derecho, vol. extraordinario, 2010.

García Marín, José María, “La Justicia del Rey en la Nueva España. Algunos aspectos. Siglos XVI-XVII", Anuario de historia del derecho español, núm. 75.

Hanisch Espíndola, Hugo, "Pedro Murillo Velarde S. J., canonista del siglo xviII", en VIII Congreso Internacional de Historia del Derecho Indiano, tomo 2, Madrid, Digibis Publicaciones Digitales, 2000.

HeRnÁNDEZ SANTIAgo, Óscar, "La justicia criminal novohispana. Entre la culpa del delincuente y la misericordia del juez”, en Gustavo César Machado Cabral, Francesco Di Chiara, Óscar Hernández Santiago, Belinda Rodriguez Arrocha, Karl Härter, El derecho penal en la edad moderna. Nuevas aproximaciones a la doctrina y a la práctica judicial, Madrid, Universidad Carlos III de Madrid - Dykinson, 2016. LóPez Ledesma, Adriana, "El Derecho Prehispánico en el Derecho Indiano: Causa criminal en la Nueva España por acciones indecentes y sublevación indígena”, Cuadernos de Historia del Derecho, núm. 13, 2006.

LóPez Ledesma, AdrianA, "La inmunidad eclesiástica en la Alcaldía Mayor de San Luis Potosí: ¿Un enfrentamiento entre fueros?”, Cuadernos de Historia del Derecho, vol. extraordinario, 2010.

Martínez de Vega, María ElisA, "Los mercaderes novohispanos: control virreinal y fraude fiscal en el primer tercio del siglo xvII", Revista Complutense de Historia de América, núm. 20.

Martínez Gijón, José, “La menor edad en el Derecho penal castellano-leonés anterior a la codificación”, Anuario de historia del derecho español, núm. 44.

Martínez Martínez, Faustino, "Ius commune, Utrumque ius: Tiempos de Derecho único, tiempos de juristas”, Glossae. European Journal of Legal History, núm. 13. [Consulta: 10 de junio, 2017]. Disponible en: http://www.glossae.eu/wp-content/ uploads/2016/11/Martinez-Ius-commune.pdf

MARTIRÉ, EduARdo, “Algo más sobre derecho indiano (entre el ius commune medieval y la modernidad)", Anuario de historia del derecho español, España, Ministerio de Justicia, 2003. 
Masferrer Domingo, Aniceto, “El 'ius commune' en la historiografía penal española. Una apuesta metodológica de apertura hacia lo supranacional y europeo”, en Orazio Condorelli (ed.), "Panta rei": Studi dedicati a Manlio Bellomo, tomo 3, Roma, Il Cigno Edizioni, 2004.

Molina, Fernanda, “Juego de artificios. Prácticas jurídicas y estrategias judiciales frente al fenómeno de la sodomía en la España moderna”, Prohistoria. Historia, políticas de la historia, año 18, núm. 24, pp. 43-68. [Consulta: 10 de junio, 2017]. Disponible en: http://www.scielo.org.ar/pdf/prohist/v24/v24a03.pdf

Murillo Velarde, Pedro, Cursus juris canonici hispani et indici/Curso de derecho canónico hispano e indiano, Zamora - México, El Colegio de Michoacán - unAm, 2008.

Ortego Gil, Pedro, “Innocentia praesumpta: absoluciones en el Antiguo Régimen”, Cuadernos de Historia del Derecho, núm. 10, pp. 71-125.

Pino Abad, Miguel, La pena de confiscación de bienes en el derecho histórico español, Córdoba, Universidad de Córdoba, 1999.

RAmos VÁzqUEZ, IsABEL, “Detenciones cautelares, coactivas o punitivas. La privación de libertad en el derecho castellano como instrumento jurídico", Anuario de historia del derecho español, núm. 77.

SAINZ GuERrA, JuAn, "Moneda y delincuencia: siglos XVI al XVIII", Anuario de historia del derecho español, vol. 2, núm. 67.

SÁnchez-Arcilla Bernal, José, “¿Arbitrariedad o arbitrio? El otro Derecho Penal de la otra Monarquía [no] Absoluta”, en José Sánchez-Arcilla Bernal, El Arbitrio judicial en el Antiguo Régimen (España e Indias, siglos XVI-XVIII), Madrid, Dykinson, 2013.

SÁnchez-Arcilla Bernal, JosÉ, Jueces, criminalidad y control social en la ciudad de México a finales del siglo XVIII, Madrid, Dykinson, 2016.

Tomás y Valiente, Francisco, El Derecho Penal de la Monarquía Absoluta (siglos XVIXVII-XVIII), Madrid, Tecnos, 1969.

Torres Aguilar, Manuel, "La pena de exilio: sus orígenes en el derecho romano", Anuario de historia del derecho español, núm. 63-64. 